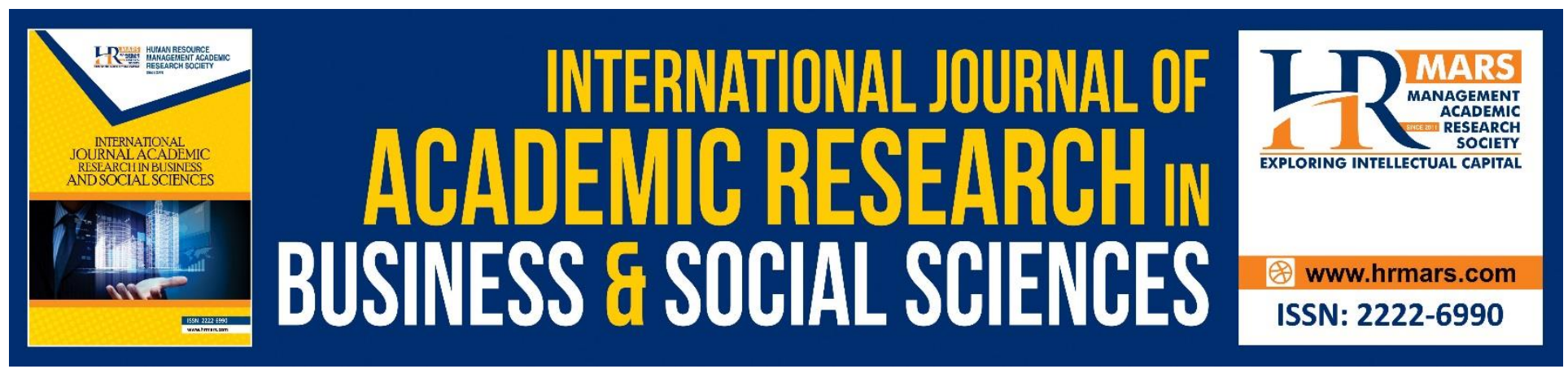

\title{
Lifelong Islamic Education: Positive Youth Development Through Ulul Albab Tahfiz Model
}

\author{
Zaidah Nor Ahmad, Mohd Mursyid Arshad, Ismi Arif Ismail, Fathiyah Mohd \\ Fakhruddin
}

To Link this Article: http://dx.doi.org/10.6007/IJARBSS/v10-i15/8236

DOI:10.6007/IJARBSS/v10-i15/8236

Received: 07 September 2020, Revised: 14 October 2020, Accepted: 18 November 2020

Published Online: 28 November 2020

In-Text Citation: (Ahmad et al., 2020)

To Cite this Article: Ahmad, Z. N., Arshad, M. M., Ismail, I. A., \& Fakhruddin, F. M. (2020). Lifelong Islamic Education: Positive Youth Development Through Ulul Albab Tahfiz Model. International Journal of Academic Research in Business and Social Sciences, 10(15), 98-115.

Copyright: (C) 2020 The Author(s)

Published by Human Resource Management Academic Research Society (www.hrmars.com)

This article is published under the Creative Commons Attribution (CC BY 4.0) license. Anyone may reproduce, distribute, translate and create derivative works of this article (for both commercial and non-commercial purposes), subject to full attribution to the original publication and authors. The full terms of this license may be seen at: http://creativecommons.org/licences/by/4.0/legalcode

Special Issue: Youth and Community Wellbeing: Issues, Challenges and Opportunities for Empowerment V1, 2020, Pg. $98-115$ http://hrmars.com/index.php/pages/detail/IJARBSS JOURNAL HOMEPAGE

Full Terms \& Conditions of access and use can be found at http://hrmars.com/index.php/pages/detail/publication-ethics 


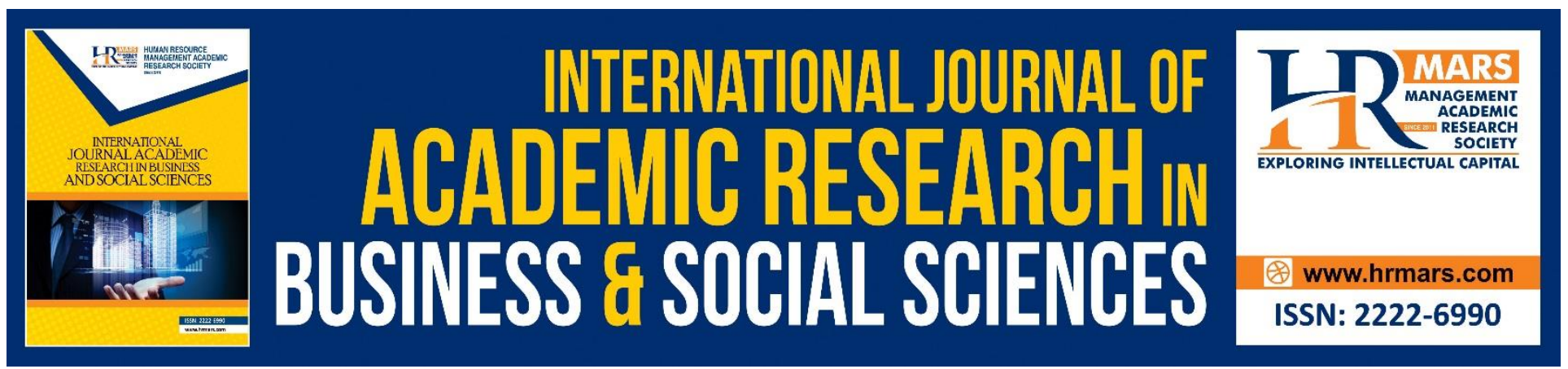

\title{
Lifelong Islamic Education: Positive Youth Development Through Ulul Albab Tahfiz Model
}

\author{
Zaidah Nor Ahmad, Mohd Mursyid Arshad, Ismi Arif Ismail, Fathiyah \\ Mohd Fakhruddin \\ Institute for Social Science Studies (IPSAS), UPM, Faculty of Educational Studies, Universiti Putra \\ Malaysia, 43400 UPM Serdang, Selangor, Malaysia \\ Email: zaidah83@gmail.com,m_mursyid@upm.edu.my, ismi@upm.edu.my,fathi@upm.edu.my
}

\section{Abstract}

Education is one of the social challenges faced by youths in Malaysia. According to the Malaysian Youth Policy, (2015), youths aged 15 to 18 years are categorized as early youth. They are under school youth category and education are emphasized on them. The education ecosystem is very important as a basis for the formation of a developed country. Continuous education as Lifelong Islamic Education (LIE) applied in the implementation of Ulul Albab Tahfiz Model (UATM) is seen as one of the important elements in education that can lead to positive youth development (PYD). Thus, using the qualitative case study methodology, this paper exploring on how LIE that takes place in the UATM can attain PYD. Data are obtained through analysis documents and semi-structured interview involving 8 students, 2 teachers and 2 guardians. The findings of the study found that the implementation of LIE able to develop individual assets and ecological assets in youth and lead to PYD. In conclusion, the implementation of UATM has a potential to develop PYD and subsequently strive to be one of the initial efforts to highlight the potential in the youth rather than the deficit approach aimed at addressing the social problems of youth.

Keywords: Ulul Albab Tahfiz Model, Positive Youth Development, Lifelong Islamic Education, Case Study, Malaysia.

\section{Introduction}

Education is one of the main pillars in the social development of the country. The European Commission, (2002) emphasizes that education should take place over a lifetime. Lifelong learning is implemented with the aim of improving knowledge, skills and competencies as well as improving personal, civic, social competencies and includes job perspectives (European Parliament and the Council of Europe, 2006). Meanwhile, Teteruk et al., (2020) remark the ability to learn throughout life that is life long learning as a human capital. This is because it shows his or her propensity to create added value to an employer and provide an appropriate income to a person.

In Malaysia, the scope of lifelong learning had further expanded by the introduction of Lifelong Islamic Education (LIE) with the objective of providing continuous Islamic Education to all as well as 
INTERNATIONAL JOURNAL OF ACADEMIC RESEARCH IN BUSINESS AND SOCIAL SCIENCES

Vol. 10, No. 15, Youth and Community Wellbeing: Issues, Challenges and Opportunities for Empowerment V1. 2020, E-ISSN: $2222-6990$ ๑ 2020 HRMARS

acquiring skills to generate income and further improve the socio-economic status of the community. Value and morals are important element (Wahid et al., 2006) that are highlighted in LIE. This means that LIE is not only provide benefits in terms of material but also in terms of personality that can realize positive youth development.

However, the Malaysian Youth Index Outcome Assessment 2017 study, found that the youth index score decreased from 71.21 in 2016 to 70.34 in 2017(Institute for Youth Research, 2018). According to National Antidrugs Agency, (2016) report, almost 7\% of new drug addiction cases detected involve school youth. In this regard, LIE is seen to be the best platform to solve this challenge.

The study found that the implementation of LIE is in line with the main goal of the UATM curriculum that to produce professional human capital, technocrats and hafiz entrepreneurs who practice Islamic teachings and possess various knowledge skills as outlined by the Ministry of Education, (2016).

The Ulul Albab group are those who hold the key to knowledge, possess great understanding, mastering various field of knowledge and are known as someone knowledgeable and wise (Yusnan \& Abdullah, 2020). The feature of Ulul Albab is also mentioned 16 times in the Qur'an and explains how important it is for individuals to become a group of Ulul Albab. According to Azis (2012 as cited in Munir, 2018), theoretically, the personality of Ulul Albab can be measured based on four measures, namely spiritual depth, moral greatness, breadth of knowledge and lastly professional maturity.

Making the youth as Ulul Albab is very important because the youth are the group that will be the leaders of the country in the future. Therefore, it is very important to make the identity development and construction of youth as one of the main agendas in a country (Abdullah et al., 2015). For that, countries with a majority Muslim population preserve and uphold the tradition of studying the Qur'an either formally or informally (Kamarudin et al., 2020).

\section{Lifelong Islamic Education}

The Lifelong Islamic Education Program (LIE) was launched in 2014 to provide an opportunity for all walks of life to follow Islamic Education (Ramli et al., 2015) and at the same time further strengthen Islamic Education itself. The implementation of LIE (2014-2025) includes three main phases, namely Building Relationships and Bridging Brotherhood followed by the phase of Enriching Human Talent and the final phase of Sustaining the Ummah which emphasizes the construction of a skilled and pious generation. According to Nor et al., (2017), LIE is a path to ensure that the target group not only has a good personality but also has skills that can improve living standards and economy. The main goal of the implementation of LIE is to produce a balanced human capital from a spiritual point of view in addition to the skills that make the individual a skilled person.

LIE in the UATM program can be an initial method of dealing with the problem of at-risk youth compared to the deficit approach. Pa'ad et al., (2017) agree that youth can improve themselves with the spiritual knowledge gained consistently and applied in life. Through LIE, Islamic education can be in the real position as an ad-din and not just an information and knowledge, (Gunardi et al., 2017). 
According to Ramli et al., (2015), Islamic education can increase personality, faith and piety to Allah and in turn can produce a balanced human capital from a spiritual and intellectual point of view as expected by the country. The development of the individual's potential to have spiritual strength, self-control, personality, intelligence, noble morals, and self-skills are closely related to education conducted consciously and structured (Wahyuddin, 2016). Emphasis on Islamic Education is very much needed in accordance with the goals desired by the country in producing individuals who are balanced and harmonious in all aspects of spiritual, physical, emotional, social and intellectual (Philosophy of National Education, 1988). In UATM, LIE process begins to take place and seen able to be a catalyst for PYD.

\section{Positive Youth Development}

Positive Youth Development (PYD) is the process of identifying and enhancing the value of youth which is valued by the youth themselves, mothers, fathers, friends, teachers, mentors and all members of the community (Damon, 2004; Lerner, 2017). In a broader sense, PYD refers to the stage at which all children need to acquire good attitudes, competencies, self-worth and social skills that make them successful adults (Mentoring Resource Center, 2007). PYD consists of 5Cs' elements, namely competence, confidence, connection, character and caring. The two main assets that are the focus for development are individual assets and ecological assets. Individual assets and ecological assets in this PYD need to be developed first and in turn will lead to the formation of 5Cs' (Lerner et al., 2005; Agans et al., 2014). The result of this combination of five elements allows the occurrence of the sixth ' $C$ ' which is a positive contribution to self, family and society (Lerner, 2017).

Hacket, (2015)described PYD as a supplement to overcome the negative influences on unhealthy risk factors such as depression, delinquency, and substance use. Youth have their own strengths and assets that can be developed in PYD. Cognitive, emotional and behavioral strengths are elements of internal strength that are the individual assets of youth to make them a better individual (Lerner et al., 2010; Arshad, 2016). Ecological assets are the external strength to PYD which is a source of youth formation with positive values. These ecological assets represent a broad input to youth consisting of four parts that are individuals within the environment, institutional networks, social networks and the ability to access a variety of resources ((Theokas \& Lerner; Agans et al., 2014). 


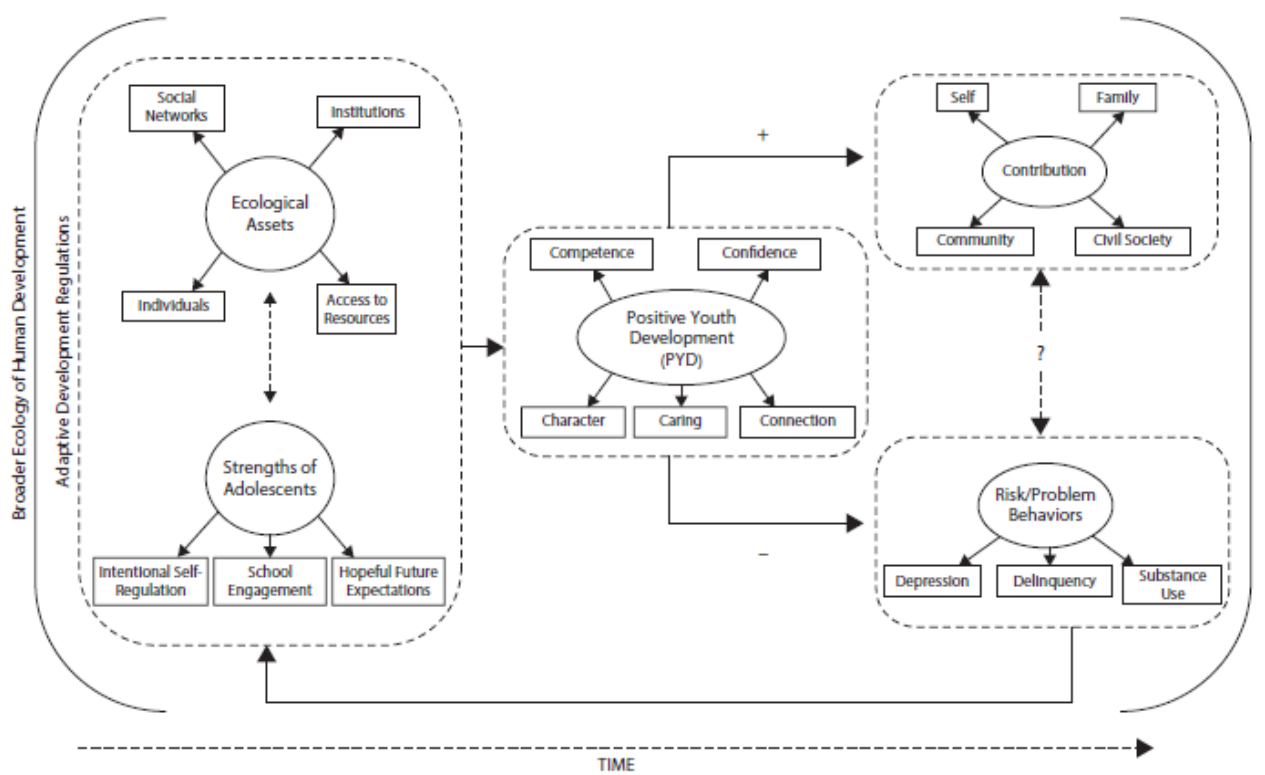

Figure 1: A Relational-Developmental-Systems model of the individual $\leftarrow \rightarrow$ context relations involved in the Lerner and Lerner conception of the PYD developmental process, (Lerner et al., 2015).

The element of competence is the motivation and ability of youth in creating public and social relationships between family, community and society and the competence of youth in connecting elements of local culture and retention to physical and emotional health (Lerner et al., 2010). The second element (confidence) is the inner strength that allows youth to have a positive inner sense of self-worth and have confidence in the future. According to Agans et al. (2014), connection in the context of PYD includes positive relationships with individuals and institutions that can influence healthy lifestyles, bilateral relationships between individuals and peers, families, institutions and communities. Character include the nature of respecting social and cultural norms, maintaining attitudes, morals and integrity and youth are considered to have a positive character when maintaining those traits at all times even without being seen by other individuals (Geldhof et al., 2015). The next element is caring. Caring is the feeling of sympathy and empathy for others. According to Lerner, this element is important to raise the spirit of youth to contribute and serve the community (Mentoring Resource Center, 2007).

The five development elements in this PYD model will only be achieved with the full involvement of all parties including family, friends, school and community (Mentoring Resource Center, 2007). Efforts can be facilitated by giving priority to the learning process undergone by youth (Lee et al., 2012). Spiritual factors among youth are also beneficial for the purpose of youth development ( Lerner et al., 2008; Hacket, 2015; James \& Fine, 2015).

\section{Positive Youth Development through Lifelong Islamic Education}

According to Hacket (2015), like PYD, religious education has the potential to trigger youth initiatives or motivate youth by engaging themselves in healthier activities or (Matos et al., 2018) . Characteristics of religious education should have a convincing, inspiring nature and involve young people (Hacket, 2015). In the context of this study, Islamic Education has the characteristics described by Hacket. Islamic Education invites all ummah regardless of age to equally appreciate the knowledge 
and teachings that can be taken from Islamic Education. Therefore, this education needs to be learned throughout life because the knowledge and practice of Islamic education is comprehensive and convincing and can ensure the well-being of life in this world and the hereafter (Suhid, 2007).

When youths have strong spiritual qualities such as fulfil commitment exceeds self-interest and or show a tendency to engage in religious activities, they will get better performance in school, less likely to show risky behaviours, can involve in their communities more vigorous, more likely to engage in voluntary activities and engage in social and political activities (Good \& Willoughby, 2006; Putnam \& Campbell, 2010; Checkoway \& Gutierrez, 2011, as cited in Hacket, 2015). On the other hand, individual might be at risk of negative psychological and behavioural outcomes for the lack of religious and spirituality belief (Sarizadeh et al., 2019).

Youth who have spiritual strength are more likely to be generous, inspiring or motivating to contribute kindness to society. This is in line with the evolving goals in the PYD model (James \& Fine, 2015). Shek et al., (2019) added that spirituality is an important aspect that put up sufficiently great impact in the formation of youth character because it is very closely related to the moral aspect in the development of adolescent character. Youth also have a more positive development when they see spirituality as an asset in their lives. According to James and Fine (2015), youths who consider themselves to have a spiritual nature get higher scores in PYD indicators. This spiritual nature is present in Islamic Education and its importance to be a subject to be learned throughout life.

\section{Methodology}

This study uses qualitative research with a case study approach to make an interpretation of how the LIE experienced by the informants can construct PYD. For data collection purposes, semi-structured in-depth interview and document analysis is used.

Selecting the right and appropriate informants is an important part of a qualitative study that aims to deepen and enrich information (Silverman, 2013). Therefore, the researchers use the purposive sampling to ensure suitable informants for this study can be identified. The informants of this study consisted of school youths who were 16 years old and under the education system who implemented the UATM program. The researchers also selected the tahfiz teacher who took on the responsibility of ensuring that the students understood the verses of the Quran by teaching the subjects of Hifz alQuran and Maharat al-Quran. The researchers also involved a guardian whose son was already an informant as the informant of this study so that triangulation can be implemented. All informants agreed to be interviewed in depth and gave consent for the interview to be recorded.

In qualitative research the credibility of the study lies with the researcher himself (Patton, 2015). This credibility depends on the ability and capability of the researcher (Golafshani, 2003). Therefore, the researchers are always sensitive to non-verbal aspects such as style and expression highlighted by the informants during the interview conducted and responsible for the data at the analysis stage until the study process ends (Seidman, 2013).

The data obtained were analyzed using the constant comparative method as suggested by Merriam (2009). After reaching saturation point and all the data have been collected, the researcher combines the data and segregates according to the same aspects. This process is called category. This method 
allows the researchers to make a comparison of all the segments formed to identify the similarities and differences of data from all informants especially in the category construction process. There are many categories developed. This important process assists the researchers in forming the final theme.

To protect the researchers from the element of bias, peer-debriefing involving feedback sessions with members of the research group was conducted by reviewing the findings obtained after the period of collection and validation of study data.

\section{Results and Discussion}

The findings show that UATM has the potential to form school youth as students who practice LIE and can build PYD. The constant comparative method used has formed five main themes that support the elements found in PYD namely build self-competence, increase self-confidence, build positive character, create Shariah-based social bonding, cultivate values and caring nature. The general structure of the findings is presented in Figure 2 as follows:

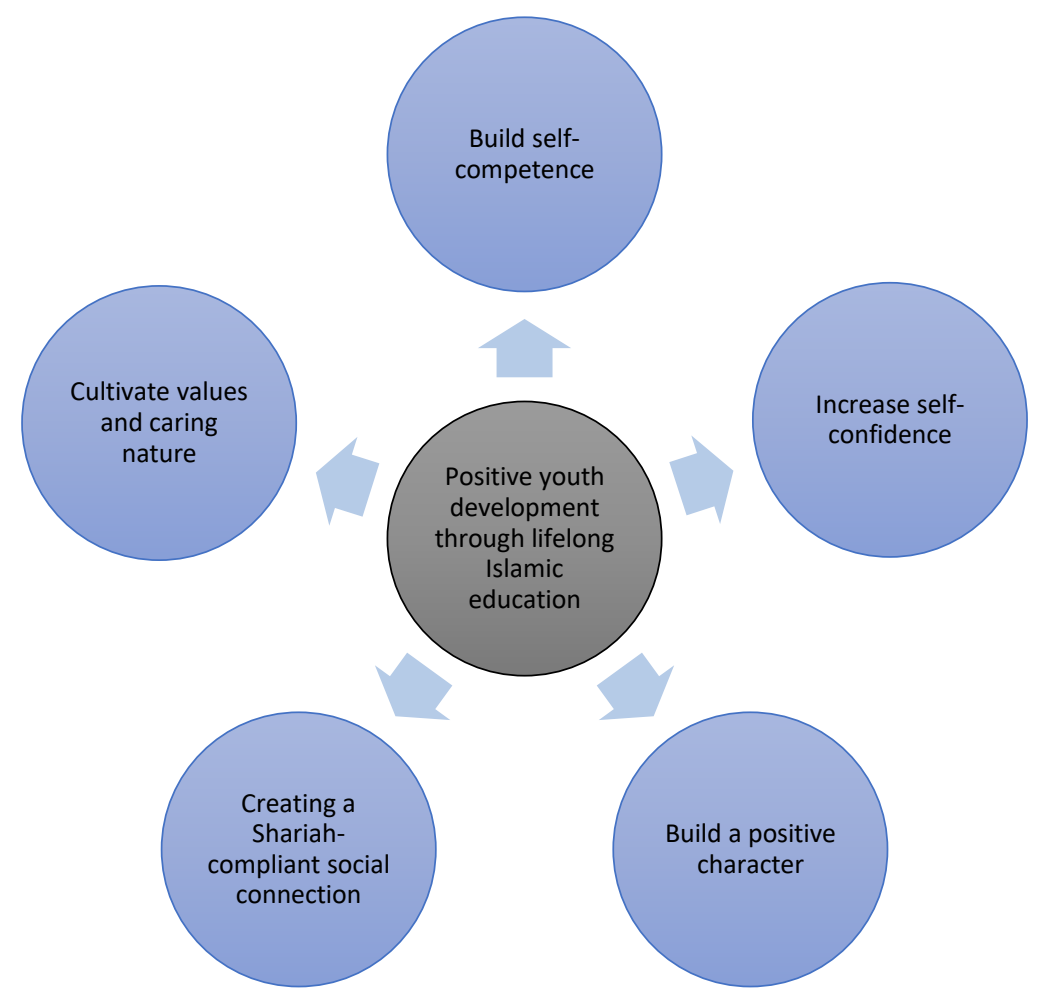

Figure 2: General structure of PYD element formed through LIE.

\section{Build self-competence}

Findings show that LIE can build self-competence in school youth which is demonstrated by the ability to lead and the ability to realize goals. This in turn lead to the construction of PYD.

\section{Ability to lead}

Exposure of leadership to school youth is very important. This is to create the nature of leadership earlier in school youth and in preparation for them to become national leaders in the future. Based on the interviews conducted, school youths are given the opportunity to hold positions that are 
appropriate to their ability to increase their potential. For example, Student 5 was appointed as the Head of the Surau Unit in BADAR, namely the Badan Dakwah dan Rohaniah (Dakwah and Spiritual Body). Student recount the duties and responsibilities they hold can instill the nature of leadership in themselves and be able to convey to others. The willingness of students to invite others to do good shows the value of leadership that exists in students. He describes:

"...I am part of the Surau. Head of Surau Unit. If the Head of the Surau Unit I have to direct, for the other students. For the students, there is the head of the Unit himself. That means I have to make sure the surau is clean. I have to call the form 1 boy to sweep, tidy up, tidy up the Quran. This Quran, Ulul Albab, is indeed related to BADAR. Delivering dakwah. Dakwah actually invites. The meaning of dakwah invites actually, the Arabic language. We have to encourage people to do good things...".

The learning process in the UATM program involves many repetitive activities to strengthen students' knowledge. The process of continuous repetition can form the practice of LIE in school youth and this can help to further strengthen the existing knowledge and give encouragement and readiness to school youth to be a leader. According to Student 1 , he is ready to reprimand and give tazkirah because of the knowledge he has. He said:

"...when I want to talk, to reprimand, to give tazkirah, the Islamic knowledge that I learned, I can use to share it with people. For example, not everyone reads Islamic novels, not everyone learns about Islam, then they really remember, really understand, really .. what, applied Islam in their daily lives. That, I use that knowledge to reveal to them...".

Leadership involving more followers should start in a smaller scope. In addition to the opportunities available at school, leadership values can be created starting from home. This family leadership can further enhance the competence of youth to become leaders for larger groups of individuals such as national leadership. This is stated by Student 7. He is ready to lead the family because the deeper understanding he has can be shared with other family members. He said “... because I am a man, I will have a family, I will get married. In sya Allah I will push my wife, my sisters. If my sister did something wrong, I can reprimand her...".

Guardian 1 also added issues regarding leadership. According to him, based on the observations of his own son as well as based on his involvement in having a role in the Parents and Teachers Association, he found that the youths attending the Ulul Albab program have leadership values in themselves. However, he suggested that these skills to be further enhanced beyond the achievements of students who are not from the UATM program. He said:

“... That leadership does exist. But if we could compare leadership with ordinary children. Our expectations are high. Leadership, when people say these boys do have leadership, but we want high leadership. If there is anything our children can be the one who come forward..."

Based on these findings, it is found that the leadership ability that exists in school youth can form a general and social relationship between family, community and society that leads to the construction of PYD (Geldhof et al., 2015). Capabilities in this leadership are also seen to be born because of the increase in youth values gained through the support system from the family and the education system itself (Kiely et al., 2011). 


\section{Ability to realize goals}

Based on the interviews conducted, the researchers found that school youths have the ability to achieve the goals that have been set for them and at the same time be able to face the challenges that come and will come. Students can overcome any issue better and think about the impact in the future as a result of the actions taken today. Student 8 recounted that he would always maintain the title he brought as a person who memorized the Quran as the objective in the implementation of the UATM program. This is because he has been thinking of the effect if he denies the title he is carrying. He is confident that if he does not acknowledge the title, he will be more likely to fall into bad deeds. On the other hand, they will feel more secure than doing bad deeds because other will realize that they carry the title "Hafiz Quran". He said:

"...do not throw away the fact that you have memorized the Quran. Because when we have memorized the Quran and people ask if we memorize the Quran, then we say "No" that's mean we have removed the title. It will make us feel 'I do not memorize the Quran so I can do what I want'. But when we said, "Yes I memorized the Quran" people must be thinking, okay to do anything with him must be a little careful...".

Student 2 also shared his experience of having the ability to form positive human relationships. According to him, the results of religious education received made him able to change the way of thinking compared to his previous way of thinking. For example, he is no longer prejudiced against society because he is aware of the adverse effects that will occur on his thinking that can affect life now and in the hereafter. He said:

"... Suppose we did not know anything about this law before. So when we want to be in this society, I think I have a judge-like attitude. So I'm like 'Hey, he's bad', I can't be friends with all that. So when I learned about religion all that, the association in society I learn to accept even though he was like that, I accepted and I tried to change it in an informal situation, meaning unconscious, we are slow try to make it better...".

Based on the discussions, the researchers found that school youths have the potential to be more advanced with the thinking patterns that they can practice. The application of intellectual skills is relevant to enable them to build PYD (Lerner et al., 2005). The ability of school youth to develop skills to achieve their goals indicates the development of self-competence in youth (Geldhof et al., 2015) and in turn leads to PYD.

\section{Increase self-confidence}

LIE was found to be able to build self-confidence in school youth. School-going youth can build confidence in self-efficacy and can increase confidence to stand out and this will give rise to PYD.

\section{Build self-confidence}

Based on the findings, school youths show that they have confidence in their abilities. School youths feel they have an advantage over others which causes them to feel more confident in their own abilities. Student 2 tells:

“... for an example like me when I was outside the school. We feel like we are small because we are not familiar with outsiders. But because we know a little about the knowledge of the hereafter, we learn a little about the laws of religion. When that moment come, even though 
we are odd in it we are confident. We are not awkward because we know how to do it all right. So the confident came from there..."

The same thing is also supported by Student 1. He said with the advantage of existing knowledge, has given confidence in himself, "... when we have a lot of knowledge, it will automatically convince us...".

According to Teacher 1, the Quran itself is indeed a special miracle. The Quran will make its practitioners more enthusiastic and self-confident. He said, "... This man when there is a disaster, what will he feel? He will feel down. But when with the Quran itself, this Quran teaches him to be more mature...".

Learning Islamic education in more depth sourced from the Quran will also create a high level of confidence in students towards Allah. Student 5 recounts his experience which clearly shows he has a firm belief in God's promises. According to him:

"... Because there is a case aaa, he what, he learned tahfiz. He always has to be angry with his ustaz, because it is difficult to memorize. Then he didn't do tasmik anymore, then that guy was like stress. He's kind of stressed. He is stressed because of the Quran. That means that thing is not right because the Quran does not stress people. Because the Qur'an is the word of God. There is no way God do not want to give us. What is our sin? That means God must have. It's easy, we just need to put more effort. After all it depends on how much we put on our effort....".

It clearly show that students see that knowledge that they gained from studying the Islamic Education had increased their confidence level. According to (Geldhof et al., 2015), the ability of youth to determine the form of resources needed to build confidence has increased self-confidence in themselves. However, he said that the construction of this confidence is also influenced by the level of confidence in them to face obstacles and subsequently achieve a meaningful impact in the youth.

Increase confidence to stand out

The findings of the interviews also show that Islamic education learned throughout life can increase the self-confidence of youth to stand out positively. This was acknowledged by Student 2 . He said although he was among the leaders, if there was an offense committed by any leader, he had the confidence to reprimand especially if the offense involved religious issues. He believes that if a mistake is corrected in a wise way, it will definitely have a good impact. He said:

“... So I see that, for example, people who make mistakes, are in conflict with Islam, but they do not realize that they make mistakes. So from there, when it happen among leaders, we need to have a sense of confidence to reprimand fellow leaders because if we reprimand with the right knowledge they are able to think rationally, he might apply the knowledge he gets... ".

This statement was also reinforced by Student 8. He expressed his readiness to move forward because he has self-confidence as a result from the knowledge he gained in school. He said:

“... at the age of 16 years old, if you want to be exposed to primary school children, talk about memorizing the Quran, talk about religion, do not talk about religion, but associate life with 
the Quran, God willing. So far, I can relate to it. I can talk to people about the Quran, it is closely related to human life...".

Student 7 also talks about the confidence in oneself to stand out to the community. He was ready to become a priest even though the congregation was older than him. He said, "... if I stop near the RnR, I always do the same, I look like aa, I asked the person behind me to pray in congregation? I offer myself..Maybe from that people will..people will be affected as well... ". He also added why it is necessary to continue to gain knowledge. He said with the title of student Ulul Albab Tahfiz, he will certainly be a place of reference. Therefore, he needs to continue to gain knowledge in order to increase his self-confidence and ability to share knowledge with the community. He said, "... We will be the place of reference. If we do not know, we must be ashamed. From there we will feel like learning more, feel like learning, we will want more religious knowledge, we will learn more religious knowledge...".

According to teachers, school youths are provided with various knowledge and skills to increase their potential. Teacher 1 tells students are given the opportunity to speak in front of the assembly day to increase their confidence. He said, “... most students will not be ashamed. Every Monday of the assembly we turn the students forward. No one refuses. There is self-confidence that is formed...".

From these findings, knowledge can increase self-confidence to move forward. In PYD, confidence comes from internal strengths that are closely related to building positive self-esteem as well as positive youth identity and feelings (Agans et al., 2014). According to Samsudin, (2007) lifelong education can unleash the potential of oneself to make oneself more efficient and skilled which in turn leads to the construction of PYD. LIE can certainly improve the competencies and skills of youth in the field of religion along with self-confidence and in turn lead to the construction of PYD.

\section{Build a Positive Character}

The findings of the study also found that LIE was able to build a positive character. Schooled youths were found to exhibit industriousness and strengthen the integrity that could eventually build PYD.

\section{Charismatic and Positive Personality}

The PISH process that school youths go through has also succeeded in instilling a positive personal nature in them. Youth become more resilient in carrying out their daily routines and responsibilities as a student. According to Student 2, "... I think I learned the meaning of not giving up or not wanting to always ask for human help. Even if we ask our parents for help, one day we will have to do everything ourselves. I think we have that support actually comes from Allah... ".

Apart from that, the issue of hygiene has also been touched by school youths. According to one of the school youth, the principal of this school emphasizes the aspect of cleanliness from the classroom, dormitory to the toilet. According to Student 3, he sees cleanliness as something that must be fulfilled and not done for other purposes such as competition. He said, the issue regarding cleanliness itself is mentioned in the Quran. He said, “... cleanliness in Islam is like aa..we are all not..not wanting to be clean because...because of what..because all the competition, not to win. Allah has told us that just like we clean our body, so that we can feel more comfortable. Sleeping in the tidy dorm all that 
are to make us more comfortable...". In fact, the issue of cleanliness of this memorization place was also mentioned by Teacher 2 . Teacher 2 said, “... We have to take care of our memorization place. We have to make sure our place of worship is clean...".

This shows that cleanliness is an important basis in seeking knowledge. At the same time it helps to shape the character of students into school youths who have a charismatic and positive personality. According to Agans et al. (2014), an act that involves respect for social and cultural rules in addition to having a good attitude, is a form of positive youth character development.

\section{Strengthen the Nature of In tegrity}

Based on the findings from the interview session, it was found that school youths can strengthen the nature of integrity in themselves. They manage to become more responsible to themselves. Student 2 tells he to try to make the most of all the time he has with worthwhile things. He said:

"... 5.30 like that just went up to the dormitory. I went up, I washed all my clothes, took a shower. At 6.15 that kind of went down to eat. So, I hope he can have less time. At 6.30 I entered the classroom. 6.30 until 7 o'clock, if there is homework, I will prepare homework first, otherwise I will do tahriri. But because I already finished memorizing the Quran, I will use my free time to memorize it. I memorized, I repeated it..remember it... ".

School youths set a good example to be emulated by displaying the nature of trust and responsibility. In fact, they managed to stop bullying cases in schools which if previously were quite frequent. This is narrated by Student 1 himself:

“... But start from form 5 this year, most of the students do stop that thing. There have not been very much like the very outrageous orders. For examples, it was considered normal in the dormitory; like eating at the dining hall right in line, he is like ... the senior student did not wait for his turn. Those are the old days. But since this year form 5 batch, it has been changed, even if they were late, they will still line up, behind the juniors, it doesn't matter. Eat .. because we want to stop things like that (bullying). And, we, I am trying to tell my batch to continue that good thing...".

For Student 4, in the process of lifelong Islamic education, he said that the effort that is often made to become a habit and a routine to. Student 5 said "... when entering this religious school, you have to follow; After the prayer, read it, read it. I wish I had followed. So when I follow, it must be good because he brings me closer to Allah...".

According to Geldholf et al., (2015), youth are considered to have a positive character when maintaining and practicing that character all the time and continuing it even without anyone else noticing. In this case, he has the potential to have a positive character because his belief in God has given awareness of all the impact that will be obtained based on the actions taken. The existing thinking ability allows school youth to think more rationally for whatever decisions and actions are taken.

\section{Creating a shariah compliant social connection}

In creating PYD, the findings of the study found that LIE can create a shariah-based social connection. School youth create positive social networks and maintain relationships according to Islamic law. 


\section{Creating a positive social network}

Based on the findings of the interview, it was found that lifelong Islamic education can help school youths form a positive social network. For example, Muslims, especially men, are strongly encouraged to perform congregational prayers in masjid or surau. With this, social networks can be formed positively. This was acknowledged by Student 3. He went to perform prayers in congregation at the masjid and at the same time practiced the practices he had learned. These practices will certainly be practiced throughout life. He said, “... like a man is encourage to pray in the masjid. So, it really looks like we really practice what we learn. We go to the masjid, then praying tahiyatul masjid. Because we had learn it in Islamic education...".

In addition, positive social networks can also be formed with the presence of school youths to talks held at masjid or surau. Student 7 said he attended a talk held at a masjid around the residential area where he lived. He said, "... talk near the mosque near my house also in sya Allah I will go...".

For Student 4, with this UATM program, he can improve his communication skills. Good communication skills are important in creating social networks. He said, “... with knowledge he gained from Ulul Albab program, I can communicate more with people. I'm the passive type, I don't like talking to people very much. But after memorizing this, I feel okay to communicate with people...".

According to Agans et al., (2014) youth need to build external networks for them to exhibit positive values that drive the ability of youth towards the construction of PYD. With the external network youth can form a variety of good skills for youth to become positive youth.

\section{Maintain relationships according to Islamic law}

Although Islam has set boundaries in socialize, especially when it involves different genders, Islam still allows social relationships to be formed as long as it is in accordance with the laws and rules that have been set. Based on interviews conducted on school youths, researchers found that school youths maintain a good relationship between men and women in line with what is prescribed in Islam. With LIE, school youths can learn more about how social networks allowed in Islam. With the existing knowledge possessed from the UATM program, school youths show a positive social network has been formed. Student 1 tells:

"... If in the community like the neighborhoods, right now it has started..what, not associating with men with women. Now it's like if I.sometimes, do hangs out with my neighbors, but with male friends. With the women are like outside, like there is this house, they have a hut in front of the house. So if you want to hang out with that woman near the hut. Means, public, public. No closed place. So there is no, there will be no slander. Because people can see what we do, and parents are in the house..." .

Student 2 also said the same thing. According to him, communication between male and female students only exists when there is a need to do so. He said, "... here we will have a limit in mingle. So in that case, it seems that conversation between the man and the woman is not impossible, but rare. So it feels like we will talk to men when there is a need..." . This was also agreed by Student 7. He said, "... I feel more, like a little more shy with the female. That's what we learned. Ikhtilat, the association of men with women. Boundaries of men and women...". 
INTERNATIONAL JOURNAL OF ACADEMIC RESEARCH IN BUSINESS AND SOCIAL SCIENCES

Vol. 10, No. 15, Youth and Community Wellbeing: Issues, Challenges and Opportunities for Empowerment V1. 2020, E-ISSN: 2222-6990 @) 2020 HRMARS

Interviews with parents found that they were aware of the need for positive interactions with the community. This aims to create and further strengthen the friendship among the people. The guardian 2 said, "... when we got invitation for a ceremony we bring these boys, to get to know people...".

Lerner et al. (2005) and Agans et al. (2014) explain the important role of social networks as ecological assets. It complements individual assets and serves as an agent for the construction of PYD.

\section{Cultivate values and caring nature}

Findings from the study found that LIE can cultivate a caring nature. This caring nature encourages school youth to give good advice and build the value of love. This in turn brings youth into positive youth.

\section{Encourage others to do good things}

The process of education received by school youths has formed a good personal value in them. Findings from interviews conducted on school youths found that school youths have the ability to solve problems with their own communication skills by giving words of advice to friends in need. According to Student 1, he was often approached by a friend who was facing a problem and asked for his advice and help to solve the problem. He said, "... Because with Islamic knowledge, if you want to advise people later, and since $u$ are the General Leader, it is normal if there are students who have problems, suddenly meet you at night in the dorm and say," Brother .. I have a problem "what is all right.. Later I can, with my knowledge, Islamic knowledge, accordance to his situation, I can use the knowledge to serve them...".

The statement was also reinforced by the findings obtained from Student 5. He said the UATM program is closely related to da'wah which specifically invites people to do good. He said, "... This Quran, Ulul Albab, is indeed related to BADAR. Delivering da'wah. Dakwah actually invites. The meaning of da'wah invites in fact, Arabic. We have to encourage people to do good things...".

According to Abdullah et al., (2015)) ideal and excellent youth not only contribute to economic development but also fulfill social responsibilities to society. In conjunction with that, the social networks can be built and lead to the construction of external assets for youth and in turn lead to positive youth development (Balsano et al., 2009).

Build the value of caring

In addition to good intentions, Islam also encourages its people to have the value of caring. The value of caring is the nature of empathy and sympathy for others in the youth. From the interview analysis data obtained, the researchers found that school youths have the value of caring in themselves. Student 4 expressed that he loves his family members and hopes that with the knowledge received can give him an advantage to guide other family members to have success in the hereafter. He did not just think of the pleasures of the hereafter for himself alone. He said, “... When we study here, I hope he will make me feel close to my family, because I have to take care of people too, I have to guide people, I am not the only one who wants to go to heaven. Have to pull my family and others too...". 
Student 1 also gave a statement on the nature and value of caring. Based on the knowledge gained from Islamic education, he found out that many Islamic figures can be an example to follow because of practicing the value of this love. Although these figures are greatly feared on the battlefield, but they have a high value of love. He said:

"... So we can take from the history of Islamic figures for us to follow in our lives. An example of such a gentle person, in the outside world is really good with everyone. He is full with love. He is known for his gentle nature. So we can use that to show our love...".

Student 2 also said the same thing. According to him, as ordinary human beings who have many weaknesses and are in dire need of clues, examples and role models shown by the Prophets based on the sirah, show that it is very appropriate to follow. He said, "... When we study, we read the stories of the Prophet. The Prophet also always showed his love for his children, for his wives. So that kind of love is important...".

Interviews with Teacher 1 also found that this trait can be formed with Quranic education emphasized in schools. This is because in the Qur'an itself, there is a lot of emphasis on personality and manners. Furthermore, if the Qur'an is the main source of knowledge for lifelong Islamic education, of course this value of love can be applied more firmly. He said, “... but if he is always with the Quran and always with Islamic education for the rest of his life, he will focus on his personality, all manners. He will indeed have the values and caring nature...".

The same thing is also said by Teacher 2. According to him, by reading the Qur'an, it makes the reader to have soft-hearted and be motivated to do good deeds. At the same time, it will instill the nature of love in the reader who tries to understand the verses- the scripture in question. He said:

"...softens his heart when he reads the Quran. That's one of the effects. That is when he talks about the greatness of Allah, what Allah gives ... in short, that is awareness. When they have awareness from the Qur'an and the teachings of Islam that we pin, it will be helping to create their personalities. When they have the personalities, the feeling of caring will come little by little".

In PYD, youth are placed to have feelings of affection by having a sense of sympathy and empathy for others (Agans et al., 2014). According to Geldhof et al. (2015), to create positive youth, the feeling of loving others especially those around youth, is very important. The ability of youth to have this trait shows the potential for positive youth development.

\section{Summary and Suggestions}

LIE that occurs in this UATM program becomes a path to open a clearer perspective on the construction of PYD. The result of this LIE has further strengthened the ' $5 C^{\prime}$ ' elements that are competence, confidence, character, bonding and caring as well as the sixth $\mathrm{C}$ contributions. LIE experienced by school youths can further strengthen the individual assets and existing ecological assets of youth to form a positive character of school youth. Finally, an understanding of the potential of LIE can help in realizing the construction of PYD among Malaysian youth.

LIE does not only occur within UATM as in this study. Researchers suggest that more LIE programs be made in the form of non-formal learning to have a positive impact and provide opportunities for dropouts who are youths at risk towards PYD. As discussed earlier, LIE not only emphasizes the 
success of the hereafter but balances the importance of worldly and ukhrawi knowledge. Opportunities to follow LIE informally can help to address the problems of youths who have dropped out and at the same time can address other problems that exist among the at-risk youths. Therefore, the relevant parties can use this study as a reference to develop youth development modules through LIE.

In addition, based on the findings of the study, the researcher suggested that the empirical findings from this study can be the beginning of further studies related to PYD through LIE in youth development from different perspectives such as the study on non-schooled youth from tahfiz schools. Since this study is in the form of qualitative research, the researchers suggest that the study in quantitative form can also be conducted. The findings from these studies can be used to make a comparison in better understanding and deepening of the lifelong Islamic education process among school-age youth with a regular curriculum and school-age youths who are in the UATM program.

\section{Conclusion}

The results of this study have successfully explored lifelong Islamic education among school-age youths as a catalyst for positive youth development. The findings of the study show that the Ulul Albab Tahfiz Model program has features that make youths school as lifelong learners with a focus on Islamic subjects. Indirectly, the results of this study can help various stakeholders in formulating youth development programs, especially related to efforts to improve knowledge that emphasizes the spiritual aspects and Islamic knowledge. This study can also help to further expand the implementation of LIE among the youth to achieve PYD and drive to develop, peaceful, and prosperous country.

\section{References}

Abdullah, N. S. N., Maamor, S. \& Wahab, N. A. (2015). Pembangunan Belia Dari Perspektif Pengurusan Islam. Journal of Global Business and Social Entrepreneurship (GBSE), 1(2): 61-76.

Agans, J. P., Champine, R. B., DeSouza, L. M., Mueller, M. K., Johnson, S. K., \& Lerner, R. M. (2014). Activity Involvement as an Ecological Asset: Profiles of Participation and Youth Outcomes. Journal of Youth and Adolescence, 43(6): 919-932.

Arshad, M. M. (2016). Pembangunan Belia Positif Melalui Proses Pementoran dalam Program Kepimpinan Belia Malaysia. (Unpublished doctoraldissertation). Universiti Putra Malaysia.

Balsano, A. B., Phelps, E., Theokas, C., Lerner, J. V., \& Lerner, R. M. (2009). Patterns of early adolescents' participation in youth development programs having positive youth development goals. Journal of Research on Adolescence, 19(2): 249-259.

Damon, W. (2004). What is Positive Youth Development? The ANNALS of the American Academy of Political and Social Science, 13(24).

European Commission. (2002). European report on quality indicators of lifelong learning. European Report on Quality Indicators of Lifelong Learning, June. http://www.seeeducoop.net/education_in/pdf/eu-report-livelong-oth-enl-t05.pdf.

Geldhof, G. J., Bowers, E. P., Mueller, M. K., Napolitano, C. M., Callina, K. S., Walsh, K. J., Lerner, J. V., \& Lerner, R. M. (2015). The Five Cs Model of positive youth development. In E. P. Bowers, G. J. Geldhof, S. K. Johnson, L. J. Hilliard, R. M. Hershberg, J. V. Lerner, \& R. M. Lerner (Eds.), Promoting Positive Youth Development: Lessons from the 4-H Study: 161-186.

Golafshani, N. (2003). Understanding reliability and validity in qualitative research. The Qualitative Report, 8(4): 597-60. 
INTERNATIONAL JOURNAL OF ACADEMIC RESEARCH IN BUSINESS AND SOCIAL SCIENCES

Vol. 10, No. 15, Youth and Community Wellbeing: Issues, Challenges and Opportunities for Empowerment V1. 2020, E-ISSN: 2222-6990 @) 2020 HRMARS

Gunardi, S., Ghani, Z. A., Tibek, S. R., Nor, A.H.M., Ismail, N. A., Darmi, R., Saad, N. S. M., Idrus, M.M., Sulaiman, A., Abdullah, H., Jaaafar, N., Ishak, M., Ismail, \& Yusoff, I. M. (2017). Pendidikan Islam di Sekolah Tahfiz. International Conference on Lifelong Learning for Islamic Studies.

Hacket, C. (2015). Positive Youth Development and Religious Education: 73-83.

Institute for Youth Research Malaysia. (2018). Annual Report \& IYRES Financial Statements 1. https://www.parlimen.gov.my/ipms/eps/2019-04-03/ST.82.2019 - 82.2019.pdf.

James, A. G., \& Fine, M. A. (2015). Relations between youths' conceptions of spirituality andtheir developmental outcomes. Journal of Adolescence, 43: 171-180.

Kamarudin, W. A. Z. W., Kamaruzaman, A. F., Kadir, F. K. A., \& Fadzil, A. F. M. (2020). Application of the Model Memorizing the Qur'an Ulul Albab in School Imtiaz Terengganu. BITARA International Journal of Civilization Studies and Human Sciences, 3(3): 1-33.

Kiely, M., Phelps, E., Bowers, E. P., Agans, J. P., Brown, J., \& Lerner, R. M. (2011). Youth development program participation and intentional self-regulation skills : Contextual and individual bases of pathways to positive youth development q. Journal of Adolescence, 34(6): 1115-1125.

Lee,K. M., Hamzah, A., Suandi, T., \& Abdullah, A. L. (2012). Positive Youth Development and Youth Learning As Enablers In Youth Leadership Programme. Malaysian Journal of Youth Studies, 6: 130.

Lerner, R. M. (2017). Commentary: Studying and Testing the Positive Youth Development Model: A Tale of Two Approaches. Child Development, 88(4): 1183-1185.

Lerner, R. M., Eye, A. Von, Lewin-Bizan, J. V. L. S., \& Bowers, E. P. (2010). The Meaning and Measurement of Thriving : A View of the Issues. Journal of Youth and Adolescence, 39: 707-719.

Lerner, R. M., Lerner, J. V., Almerigi, J. B., Theokas, C., Phelps, E., Gestsdottir, S., Naudeau, S., Jelicic, H., Alberts, A., Ma, L., Smith, L. M., Bobek, D. L., Richman-Raphael, D., Simpson, I., Christiansen, E. D. D., \& Von Eye, A. (2005). Positive youth development, participation in community youth development programs, and community contributions of fifth-grade adolescents: Findings from the first wave of the 4-H study of positive youth development. Journal of Early Adolescence, 25(1): 17-71.

Lerner, R. M., Lerner, J. V., Bowers, E. P., \& Geldhof, G. J. (2015). Positive Youth Development and Relational Developmental Systems. In Handbook of Child Psychology and Developmental Science (pp. 1-45). https://doi.org/https://doi.org/10.1002/9781118963418.childpsy116

Lerner, R. M., Roeser, R. W., \& Phelps, E. (2008). Positive youth development and spirituality: From theory to research. Positive Youth Development and Spirituality: From Theory to Research., 4(2): 74-78.

Matos, M. G., de, Santos, T., Reis, M., \& Marques, A. (2018). Positive Youth Development: Interactions Between Healthy Lifestyle Behaviours and Psychosocial Variables. Global Journal of Health Science, 10(4): 68.

Malaysian Youth Policy. (2015), Ministry of Youth and Sports.

Mentoring Resource Center. (2007). Mentoring Fact Sheet. January, 1-4. http://educationnorthwest.org/sites/default/files/resources/factsheet13.pdf.

Ministry of Education. (2016). SPI Bil.1/2016 Pelaksanaan Tahfiz Model Ulul Albab di Sekolah Menengah KPM.

Munir, M. (2018). Membingkai Kepribadian Ulul Albab Generasi Milenial. Ta'limuna., 7(1): 45-59.

National Antidrugs Agency, Ministry of Home Affairs. (2016). Maklumat Dadah 2016.

Nor, N. M., Nowalid, W. M.W. M., \& Hassan, Z. (2017). Pelaksanaan Pendidikan Islam Sepanjang Hayat di Kolej Komuniti gabungan keperluan Duniawi dan Ukhrawi. International Conference on 
INTERNATIONAL JOURNAL OF ACADEMIC RESEARCH IN BUSINESS AND SOCIAL SCIENCES

Vol. 10, No. 15, Youth and Community Wellbeing: Issues, Challenges and Opportunities for Empowerment V1. 2020, E-ISSN: 2222-6990 @ 2020 HRMARS

Lifelong Learning for Islamic Studies.

Pa'ad, N. S., Mansor, N. H., \& Jodi, K. H. M. (2017). Remaja Bermasalah Dan Keperluan Motivasi Untuk Pembelajaran Sepanjang Hayat. International Conference on Lifelong Learning for Islamic Studies.

Patton, Q. M. (2015). Qualitative research and evaluation method (4th ed.). Sage Publication Inc.

Ramli, M. H. M., Mohamad, I., \& Esin, M. Z. M. (2015). Impak Pelaksanaan Pendidikan Islam Sepanjang Hayat: 1-14.

Samsudin, I. S., (2007). Membudayakan Pembelajaran Sepanjang Hayat: 129-139.

Sarizadeh, M. S., Najafi, M., \& Rezaei, A. M. (2019). The Prediction of Depression Based on Religious Coping and The Components of Positive Youth Development in Adolescents. Mental Health, Religion and Culture: 1-13.

Seidman, I. (2013). Interviewing as qualitative research: A guide for researchers in education and social sciences. Teachers College Press.

Shek, D. T., Dou, D., Zhu, X., \& Chai, W. (2019). Positive youth development : current perspectives. Adolescent Health, Medicine and Therapeutics, 10: 131-141.

Silverman, D. (2013). Doing Qualitative Research: A practical handbook. Sage Publication Inc

Suhid, A. (2007). Pengajaran Adab Dan Akhlak Islam Dalam Membangunkan Modal Insan. Jurnal Pengajian Umum, 8(9): 167-178.

Teteruk, K., Datsii, N., Kartashov, E., Ivashova, L., \& Ortina, G. (2020). Specificity of Forming Human Capital at It - Enterprises in Conditions of Concept Lifelong Learning. International Journal of Innovative Technology and Exploring Engineering, 9(3): 1379-1387.

Theokas, C., \& Lerner, R. M. (n.d.). Observed Ecological Assets in Families, Schools, and Neighborhoods: Conceptualization, Measurement and Relations with Positive and Negative Developmental Outcomes.

Wahid, H., Awang, J., Ismail, R., Salleh, K., \& Kadir, M. A. A. (2006). Pembangunan Modal Insan Melalui Pendidikan Sekolah Agama: Satu Kajian awal di Sekolah Menengah Agama Bandar Baru Salak Tinggi, Selangor. Ukm, 1-15. http://www.rmp.gov.my/rmp03/statindeks2006.htm.

Wahyuddin, W. (2016). Pendidikan Sepanjang Hayat Menurut Perspektif Islam (Kajian Tafsir Tarbawi). Kajian Keislaman, 3(2): 191-208.

Yusnan, M. B. M., \& Abdullah, N. M. S. A. N. (2020). The Perceptions of Teachers and Students Towards the Ulul Albab Curriculum: A Case Study of SMAKL. Journal of Quran and Sunnah Studies, 4(2). 